\title{
Alokasi Ekonomis untuk Sistem Penyimpan Energi dengan Mempertimbangkan Distribusi Tenaga Angin
}

\author{
Vicky Pria Permata, Rony Seto Wibowo, dan Vita Lystianingrum Budiharto Putri \\ Departemen Teknik Elektro, Fakultas Teknologi Elektro, Institut Teknologi Sepuluh Nopember (ITS) \\ e-mail:vita@ee.its.ac.id
}

\begin{abstract}
Abstrak-Sistem penyimpan energi telah banyak digunakan, seiring meningkatnya penggunaan pembangkit listrik energi terbarukan. Salah satu kelebihan dari sistem penyimpan energi adalah dapat meminimalkan biaya operasi sistem dan memperbaiki profil tegangan. Namun, pemasangan penyimpan energi dengan lokasi dan ukuran yang kurang sesuai akan menyebabkan biaya operasi sistem yang kurang optimal dan mengancam stabilitas tegangan, khususnya pada sistem yang memiliki pembangkit listrik tenaga angin. Karena sifat angin yang tidak pasti, sehingga menyebabkan daya yang disalurkan pembangkit listrik tenaga angin ke sistem berubah-ubah. Algoritma Hybrid Multi-Objective Particle Swarm Optimization (HMOPSO) digunakan untuk mencari lokasi dan ukuran penyimpan energi yang optimal dalam pertimbangan ketidakpastian distribusi tenaga angin. Algoritma HMOPSO mengkombinasikan algoritma Multi-Objective Particle Swarm Optimization (MOPSO) dengan teknik aliran daya NewtonRaphson dan five-point estimation method (5PEM). Metode 5PEM digunakan untuk mendiskritisasi distribusi tenaga angin. Selanjutnya, dilakukan analisis probabilitas biaya. Sistem IEEE 30-bus digunakan untuk melakukan beberapa studi kasus. Hasil simulasi dari setiap studi kasus menunjukkan perlunya alokasi sistem penyimpan energi secara optimal dan memperlihatkan keefektifan metode yang dilakukan.
\end{abstract}

Kata Kunci-Analisis Probabilitas Biaya, Five-Point Estimation Method, Multi-Objective Particle Swarm Optimization, Sistem Penyimpan Energi.

\section{PENDAHULUAN}

$\mathrm{P}$ EMBANGKIT tenaga angin mulai marak digunakan sebagai sumber energi alternatif di banyak bagian dunia [1]. Berdasarkan laporan dari American Wind Energy Association (AWEA), Amerika Serikat telah memasang pembangkit tenaga angin sebesar $40 \mathrm{GW}$ pada tahun 2010 [2].

Pembangkit tenaga angin memiliki banyak manfaat dalam keterjaminan energi dibanding pembangkit tenaga diesel, gas alam, atau batubara. Namun, terdapat permasalahan kestabilan sistem yang disebabkan oleh sifat ketidak-pastian angin. Ketidak-pastian ini menyebabkan profil angin berubah setiap waktu, sehingga daya yang disalurkan ke grid berbeda setiap waktu [3].

Integrasi sistem penyimpan energi pada grid merupakan salah satu solusi terbaik untuk menjamin stabilitas dan kualitas daya suatu sistem tenaga. Penentuan lokasi dan ukuran yang optimal dari penyimpan energi pada sistem tenaga dapat mengurangi biaya operasi sistem tenaga dan memperbaiki profil tegangan [4]. Namun, lokasi dan ukuran penyimpan energi yang kurang sesuai akan menyebabkan biaya operasi sistem yang kurang optimal dan mengancam stabilitas tegangan, khususnya pada penggunaan energi terbarukan [5].

Alokasi ekonomis sistem penyimpan energi adalah suatu metode untuk mencari lokasi dan ukuran penyimpan energi yang optimal agar dapat meminimalkan biaya operasi sistem dan memperbaiki profil tegangan namun dengan tetap memperhatikan batasan teknis yang ada. Dengan meningkatnya penggunaan pembangkit tenaga angin, maka dalam menentukan lokasi dan ukuran penyimpan energi harus memperhatikan distribusi tenaga angin.

\section{ALOKASI EKONOMIS SISTEM PENYIMPAN ENERGI DENGAN MEMPERHATIKAN DISTRIBUSI TENAGA ANGIN}

A. Alokasi Ekonomis Untuk Sistem Penyimpan Energi dengan Memperhatikan Distribusi Tenaga Angin

Alokasi ekonomis bertujuan untuk mencari lokasi dan ukuran penyimpan energi yang optimal untuk meminimalkan biaya operasi sistem dan memperbaiki profil tegangan namun dengan tetap memperhatikan batasan-batasan seperti tegangan bus, daya aktif dan daya reaktif [5]. Alokasi sistem penyimpan energi dilakukan pada sistem yang memiliki pembangkit tenaga angin. Daya keluaran dari pembangkit tenaga angin bergantung pada kecepatan angin. Sehingga, dalam melakukan alokasi sistem penyimpan energi, skenario-skenario distribusi tenaga angin harus diperhitungkan. Fungsi objektif dari alokasi ekonomis sistem penyimpan energi ini adalah:

$$
f_{o b 2}=\sum_{\boldsymbol{d}_{k=1}}^{f_{o b 1}=\sum_{k=1}^{5} p_{k} \cdot C_{k}} \sum_{s=1}^{h}\left(\frac{V_{s_{k}}-V_{s_{k}} \text { exp }}{\Delta V_{s_{k}}^{\max }}\right)^{2}
$$

Dengan persamaan biaya operasi sebagai berikut:

$C_{k}=\sum_{r=1}^{m} C\left(P_{G r}\right)+C_{w}+C_{s}$

$=\sum_{r=1}^{m}\left(a_{r}+b_{r} \cdot P_{G r}+c_{r} \cdot \mathrm{P}_{G r}{ }^{2}\right)+\mathrm{c}^{o w} \cdot P_{w}+\mathrm{c}^{o s} \cdot P_{s}$

$p_{k} \quad:$ probabilitas biaya operasi sistem pada skenario ke-

$C_{k} \quad$ : total biaya operasi sistem pada skenario ke-k $(\$ / \mathrm{h})$

h : total simpul bus

$\mathrm{V}_{S_{k}}$ exp : tegangan yang diinginkan pada skenario ke-k

$\Delta \mathrm{V}_{s_{k}}$ max : selisih tegangan maksimum pada skenario ke-k

$\mathrm{m} \quad$ : total generator 
$C\left(P_{G r}\right) \quad$ : biaya operasi generator ke-r $(\$ / \mathrm{h})$

$C_{w} \quad$ : biaya operasi pembangkit tenaga angin $(\$ / \mathrm{h})$

$C_{s} \quad$ : biaya operasi sistem penyimpan energi $(\$ / \mathrm{h})$

$a_{r}, b_{r}, c_{r}$ : koefisien fuel cost generator ke-r

$\mathrm{c}^{\text {ow }} \quad$ : koefisien biaya operasi pembangkit listrik tenaga angin $(\$ / \mathrm{MWh})$

$P_{w} \quad$ : daya keluaran pembangkit tenaga angin (MW)

$c^{o s} \quad:$ koefisien biaya operasi sistem penyimpan energi (\$/MWh)

$P_{S} \quad:$ kapasitas sistem penyimpan energi yang terpasang (MW)

(1) Equality constraint

$$
P_{i}-V_{i} \sum_{j=1}^{N} V_{j}\left(G_{i j} \cos \delta_{i j}+B_{i j} \sin \delta_{i j}\right)=0
$$

(2) Inequality constraint

$$
\begin{aligned}
& V_{\text {min }} \leq V_{i} \leq V_{\text {max }} \\
& P_{G i \min } \leq P_{G i} \leq P_{G i \max } \\
& Q_{G i \min } \leq Q_{G i} \leq Q_{G i \max }
\end{aligned}
$$

$\mathrm{V}_{i} \quad$ : tegangan pada bus $\mathrm{i}$

$\mathrm{P}_{G i}$ : daya aktif yang dibangkitkan generator i

$\mathrm{Q}_{G i}$ : daya reaktif yang dibangkitkan generator i

\section{B. Diskritisasi Distribusi Tenaga Angin}

Berbeda dengan analisis penempatan konvensional yang dilakukan pada beban besar tanpa tenaga angin, pada penelitian [6] bertujuan untuk menentukan alokasi optimal sistem penyimpan energi dengan memperhatikan distribusi tenaga angin. Penelitian tersebut menggunakan metode five-point estimation method (5PEM).

Dari penelitian sebelumnya [3] telah dijelaskan bahwa, dengan menggunakan power curve dari turbin angin, distribusi tenaga angin dapat diubah menjadi persamaan linier seperti berikut:

$$
P_{w}=\left\{\begin{aligned}
0, & \text { if } V \leq V_{c i} \text { or } V>V_{c o} \\
\alpha+\beta V, & \text { if } V_{c i} \leq V \leq V_{n o} \\
Z, & \text { if } V_{n o} \leq V \leq V_{c o}
\end{aligned}\right.
$$

$\mathrm{V} \quad$ : kecepatan angin

$\mathrm{Z} \quad$ : daya maksimum dari turbin angin

$\alpha \& \beta$ : koefisien linier

$V_{c i} \quad$ : kecepatan cut-in angin

$V_{c o} \quad$ : kecepatan cut-out angin

$V_{n o} \quad$ : kecepatan normal angin

Distribusi Weibull telah banyak digunakan untuk menyajikan distribusi probabilitas kecepatan angin, yang didefinisikan sebagai berikut:

$$
f(x \mid \lambda, k)=\frac{k}{\lambda}\left(\frac{x}{\lambda}\right)^{k-1} e^{-\left(\frac{x}{\lambda}\right)^{k}}
$$

$k$ : parameter bentuk

$x$ : parameter skala

Tujuan utama diskritisasi ini adalah mendiskritisasi distribusi tenaga angin yang bersifat kontinyu menjadi lima poin diskrit distribusi tenaga angin, dengan probabilitas pada masingmasing poin. Untuk langkah awal, dapat didefinisikan sebagai berikut:

$$
\begin{aligned}
& P_{1}=\operatorname{prob}\left(P_{W}=0\right)=\operatorname{prob}\left(V \leq V_{c i}\right)+\operatorname{prob}\left(V>V_{c o}\right) \\
& P_{5}=\operatorname{prob}\left(P_{W}=Z\right)=\operatorname{prob}\left(V_{n o} \leq V \leq V_{c o}\right)
\end{aligned}
$$

Kemudian untuk kecepatan angin sebesar $V_{c i} \leq \mathrm{V} \leq V_{n o}$, fungsi kepadatan probabilitasnya dapat didefinisikan sebagai berikut:

$$
f_{P_{W}}(y \mid \lambda, k)=\frac{\frac{1}{\beta} f\left(\frac{y-\alpha}{\beta} \mid \lambda, k\right)}{1-P_{1}-P_{5}}
$$

diketahui bahwa,

$$
\begin{gathered}
\int_{0}^{Z} f_{P_{W}}(y \mid \lambda, k) d y=1 \\
\mu_{P_{W}}=\int_{0}^{Z} y f_{P_{W}}(y \mid \lambda, k) d y \\
\sigma_{P_{W}}^{2}=\int_{0}^{Z}\left(y-\mu_{P_{W}}\right)^{2} f_{P_{W}}(y \mid \lambda, k) d y \\
\lambda_{j}=\int_{0}^{Z}\left(\frac{y-\mu_{P_{W}}}{\sigma_{P_{W}}}\right)^{j} f_{P_{W}}(y \mid \lambda, k) d y
\end{gathered}
$$

$\mu_{\mathrm{Y}}$ : rata-rata dari $P_{\mathrm{W}}$;

$\sigma_{\mathrm{Y}}:$ standar deviasi dari $P_{\mathrm{W}}$;

$\lambda_{\mathrm{j}}$ : momen sentral ke j dari $P_{\mathrm{W}}$.

Diasumsikan $\mathrm{d}=\left(\mathrm{y}-\mu_{\mathrm{Y}} / \sigma_{\mathrm{Y}}\right)$ merupakan nilai standar dari $P_{\mathrm{W}}$. Persamaan momen yang diketahui adalah

$$
\sum_{i=2}^{4} p_{i} d_{i}=\lambda_{j}
$$

dimana, $p_{i}$ merupakan probabilitas yang sesuai dengan $d_{i}$. Dengan menyelesaikan persamaan (17), maka didapatkan:

$$
\begin{aligned}
& \left\{\begin{array}{l}
d_{2}=\frac{\lambda_{3}}{2}-\sqrt{\lambda_{4}-\frac{3 \lambda_{3}{ }^{2}}{4}} \\
d_{3}=0 \\
d_{4}=\frac{\lambda_{3}}{2}+\sqrt{\lambda_{4}-\frac{3 \lambda_{3}{ }^{2}}{4}}
\end{array}\right. \\
& \left\{\begin{array}{c}
p_{2}=\frac{-1}{d_{2}\left(d_{4}-d_{2}\right)} \\
p_{3}=1-p_{2}-p_{4} \\
p_{4}=\frac{1}{d_{4}\left(d_{4}-d_{2}\right)}
\end{array}\right.
\end{aligned}
$$

Dengan menentukan nilai $d_{2}, d_{3}, d_{4}, p_{2}, p_{3}$ dan $p_{4}$, maka diperoleh probabilitas dari ketiga skenario lainnya beserta besar daya yang dihasilkan turbin angin seperti berikut:

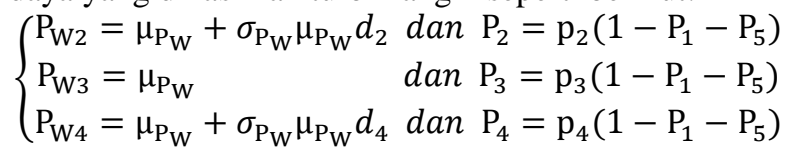

\section{PENERAPAN HMOPSO UNTUK ALOKASI EKONOMIS SISTEM PENYIMPAN ENERGI DENGAN MEMPERTIMBANGKAN DISTRIBUSI TENAGA ANGIN}

\section{A. Hybrid Multi Objective Particle Swarm Optimization}

Flowchart dari metode HMOPSO ini dapat dilihat pada gambar 1. HMOPSO mengintegrasikan beberapa metode, 
antara lain: 1) MOPSO, yang mencari posisi dan kecepatan setiap partikel untuk menentukan lokasi dan ukuran terbaik dari sistem penyimpan energi dan daya yang dibangkitkan oleh generator; 2) 5PEM, yang mendiskritisasi distribusi tenaga angin menjadi 5 skenario untuk studi kasus; 3) aliran daya Newton-Raphson, yang menyelesaikan persamaan-persamaan aliran daya dengan memperhitungkan 5 poin diskrit distribusi tenaga angin. Setelah didapat solusi nondominated maka cara menentukan solusi akhir adalah dengan fuzzy linear [7].

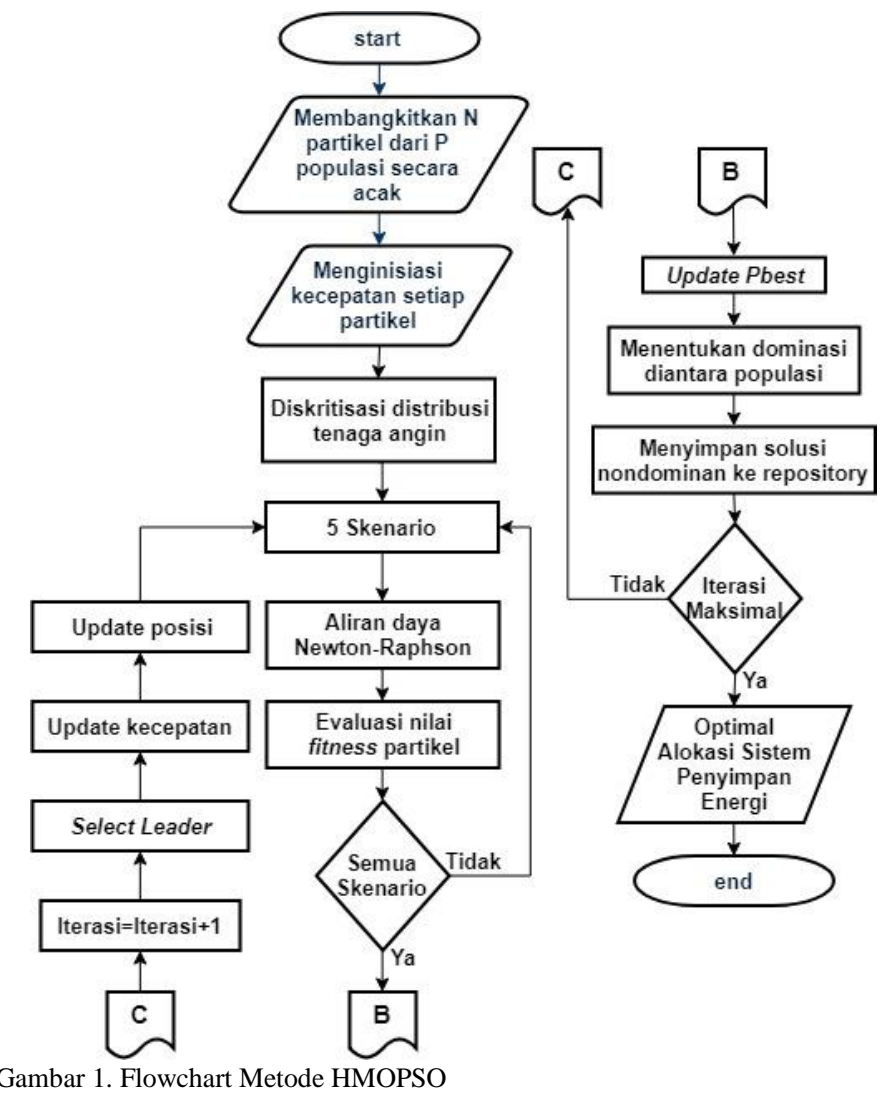

Gambar 1. Flowchart Metode HMOPSO

B. Penerapan HMOPSO Untuk Alokasi Ekonomis Sistem Penyimpan Energi dengan Mempertimbangkan Distribusi Tenaga Angin

(1) Inisialisasi Awal

Dalam memulai HMOPSO kita harus menginisialisasi beberapa parameter, yaitu:

$\begin{array}{ll}\text { Jumlah Populasi } & =50 \\ \text { Jumlah Variabel } & =29 \\ \text { Jumlah Repository } & =100 \\ \text { Bobot Inersia } & =0.4 \\ \text { Koefisien Kognitif } & =1 \\ \text { Koefisien Sosial } & =1 \\ \text { Koefisien Mutasi } & =0.5 \\ \text { Koefisien Inflasi } & =0.2 \\ \text { Ukuran dimensi grid } & =30 \\ \text { Koefisien Leader Selection } & =2 \\ \text { Koefisien Deletion Selection } & =5 \\ \text { Iterasi Maksimal } & =200\end{array}$

Populasi terdiri dari sekumpulan variabel. Variabel adalah parameter yang akan dioptimasi, pada tugas akhir ini variabel yang akan dioptimasi adalah 5 output generator dan 24 kapasitas sistem penyimpan energi pada load bus, sehingga total variabel adalah 29 variabel. Variabel tersebut dibatasi oleh batas variabel maksimal serta batas variabel minimal.

(2) Inisiasi posisi dan kecepatan populasi.

(3) Run loadflow dan evaluasi nilai fitness dari posisi populasi.

(4) Update personal best populasi.

(5) Menentukan dominasi di antara populasi.

(6) Simpan populasi yang tidak didominasi (non dominated) ke dalam repositori (rep), solusi baru yang dihasilkan ditambahkan ke repositori dan solusi yang dikuasai dihapus dari repositori.

(7) Mencari leader dari repositori.

(8) Update kecepatan setiap populasi dengan persamaan:

pop. velocity $=W x$ pop.velocity ... +

$C 1 x$ rand $x$ (Pbest - pop $) \ldots+C 2 x$ rand $x$ (Leader -

pop)

(9) Update posisi populasi dengan persamaan:

pop.posisi $=$ pop. posisi + pop. velocity

(10) Memeriksa posisi populasi yang baru dengan batasan posisi yang telah ditentukan.

(11) Run load flow dan evaluasi nilai fitness dari posisi populasi yang baru.

(12) Melakukan proses mutasi.

(13) Menentukan dominasi diantara populasi dan update Pbest.

(14) Menambahkan solusi non-dominated yang baru dari populasi ke dalam repositori.

(15) Memeriksa ukuran repositori, jika repositori melebihi batasan maka harus mengeluarkan member extra.

(16) Jika jumlah iterasi sudah mencapai iterasi maksimum yang ditentukan, maka HMOPSO berhenti.

(17) Semua member repositori yang tersisa akan diambil untuk menentukan solusi akhir dengan menggunakan metode fuzzy linear.

\section{Data Masukan}

(1) Data Sistem Kelistrikan

Pada tugas akhir ini digunakan sistem kelistrikan IEEE 30 bus yang telah dimodifikasi. Sistem ini terdiri dari 5 buah generator dan 24 beban, dimana bus 1 merupakan slack bus, bus 5, 8, 11, 13 merupakan generator bus dan yang lainnya merupakan load bus. Pembangkit tenaga angin ditambahkan pada bus 2 dengan rating sebesar $113 \mathrm{MW}$. Untuk data generator pada sistem IEEE 30-bus dapat dilihat pada tabel 1.

Tabel 1.

Data Generator Sistem IEEE 30-bus

\begin{tabular}{cccccccc}
\hline \hline Unit & $\begin{array}{c}\text { Pmin } \\
(\mathrm{MW})\end{array}$ & $\begin{array}{c}\text { Pmax } \\
(\mathrm{MW})\end{array}$ & $\begin{array}{c}\text { Qmin } \\
(\text { MVar })\end{array}$ & $\begin{array}{c}\text { Qmax } \\
(\text { MVar })\end{array}$ & $\mathrm{a}$ & $\mathrm{b}$ & $\mathrm{c}$ \\
\hline 1 & 50 & 200 & - & - & 0 & 20 & 0.038432 \\
5 & 15 & 50 & -15 & 62.5 & 0 & 40 & 0.01 \\
8 & 10 & 35 & -15 & 50 & 0 & 40 & 0.01 \\
11 & 10 & 30 & -10 & 40 & 0 & 40 & 0.01 \\
13 & 12 & 40 & -15 & 45 & 0 & 40 & 0.01 \\
\hline \hline
\end{tabular}

Sistem IEEE 30-bus yang telah dimodifikasi dapat dilihat pada Gambar 2. 


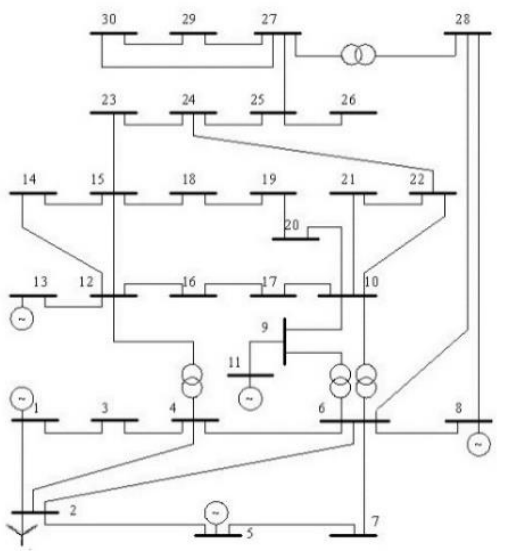

Gambar 2. Sistem IEEE 30-bus yang telah dimodifikasi.

(2) Data dan Parameter Distribusi Angin

Data dan parameter distribusi angin yang digunakan adalah data kecepatan angin di kota Madison, Wisconsin, USA. Data tersebut dapat dilihat pada tabel 2, tabel 3. Fungsi distribusi Weibull dari kota Madison dapat dilihat pada Gambar 3.

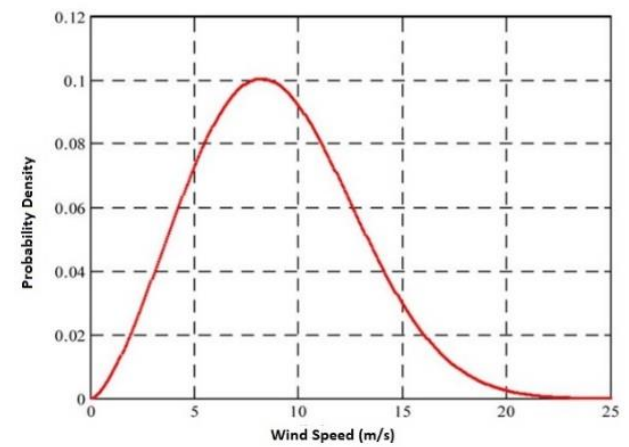

Gambar 3. Fungsi Kepadatan Probabilitas dari Data Kecepatan Angin di Kota Madison [5].

Tabel 2.

Data Distribusi Angin Kota Madison

\begin{tabular}{ccc}
\hline \hline Vcut-in & Vcut-out & Vrated \\
\hline 3.5 & 40 & 13.5 \\
\hline \hline
\end{tabular}

Tabel 3.

Parameter Distribusi Angin Kota Madison

\begin{tabular}{cccc}
\hline \multicolumn{4}{c}{ Parameter Distribusi Angin Kota Madison } \\
\hline $\mathrm{k}$ & $\lambda$ & $\alpha$ & $\beta$ \\
\hline 2.5034 & 10.0434 & -39.55 & 11.3 \\
\hline \hline
\end{tabular}

(3) 5 Poin Diskrit Distribusi Tenaga Angin

Dengan menggunakan parameter distribusi angin pada tabel 3 , distribusi angin yang kontinyu di kota Madison dapat didiskritisasikan menjadi 5 poin diskrit dari distribusi tenaga angin tersebut menggunakan metode 5PEM. 5 poin diskrit tersebut dapat dilihat pada tabel 4. 5 poin diskrit tersebut kemudian akan digunakan sebagai 5 skenario pada studi kasus.

Tabel 4.

5 Poin Diskrit Distribusi Tenaga Angin Kota Madison

\begin{tabular}{cccccc}
\hline \hline Poin (MW) & 0 & 14.54 & 55.79 & 98.12 & 113 \\
\hline Probabilitas (\%) & 6.89 & 20.44 & 40.48 & 19.92 & 12.27 \\
\hline \hline
\end{tabular}

(4) Data Koefisien Biaya Operasi Sistem Penyimpan Energi dan Pembangkit Tenaga Angin
Berdasakan Lawrance Berkeley National Laboratory [8] dan laporan dari US Department of Energy [9], biaya operasi dan perawatan dari pembangkit tenaga angin disepakati sebesar 30\$MWh. Berdasarkan Sandia National Laboratory [10], biaya operasi dan perawatan sistem penyimpan energi sebesar 40\$/MWh.

\section{HASIL DAN PEMBAHASAN}

Diperoleh grafik yang menunjukkan solusi nondominated pada gambar 4. Setelah diperoleh solusi nondominated, maka langkah selanjutnya adalah menggunakan metode fuzzy linear untuk menentukan solusi terbaik dari nondominated tersebut. Diperoleh alokasi terbaik sistem penyimpan energi pada tabel 5.

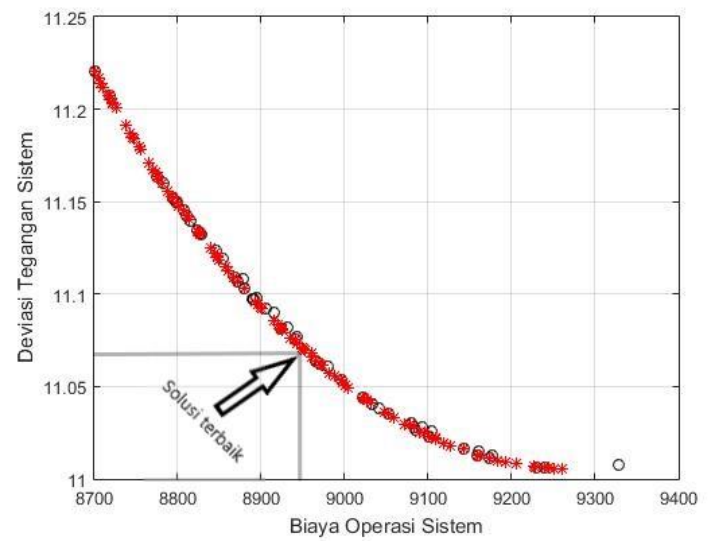

Gambar 4. Hasil Alokasi Sistem Penyimpan Energi dengan metode HMOPSO

Tabel 5.

Hasil Alokasi Sistem Penyimpan Energi dengan HMOPSO

\begin{tabular}{ccc}
\hline \hline $\begin{array}{c}\text { Lokasi Sistem } \\
\begin{array}{c}\text { Penyimpan Energi } \\
\text { (bus) }\end{array}\end{array}$ & $\begin{array}{c}\text { Ukuran Sistem } \\
\text { Penyimpan Energi } \\
\text { (MW) }\end{array}$ & $\begin{array}{c}\text { Total Kapasitas } \\
\text { Sistem Penyimpan } \\
\text { Energi } \\
\text { (MW) }\end{array}$ \\
\hline 26 & 3.5 & 11 \\
\hline 30 & 7.5 & \\
\hline \hline
\end{tabular}

Efek atau pengaruh dari integrasi pembangkit tenaga angin dan sistem penyimpan energi akan dipelajari dan dibandingkan dalam 3 studi kasus yang berbeda, untuk menunjukkan keefektifan metode HMOPSO.

\section{(1) Studi Kasus 1}

Pada studi kasus pertama, dilakukan analisis probabilistik pada sistem yang tidak dilakukan integrasi sistem penyimpan energi. Dapat dilihat pada tabel 6 bahwa biaya operasi sistem berkurang seiring meningkatnya daya pembangkit tenaga angin. Biaya operasi sistem terus berkurang dari $9532.5 \$ / \mathrm{h}$ sampai $8750.4 \$ / \mathrm{h}$ seiring dengan meningkatnya daya pembangkit tenaga angin dari 0 sampai 113 MW. Namun deviasi tegangan masih sangat besar. Dapat dilihat ketika daya pembangkit tenaga angin bernilai 55.79, tegangan pada bus 11 dan 13 adalah 1.082 dan 1.071, sedangkan tegangan pada bus 30 sangat rendah, yaitu 0.967 .

\section{(2) Studi Kasus 2}

Pada studi kasus kedua, diimplementasikan analisis optimal load flow untuk menentukan alokasi terbaik sistem penyimpan 
Tabel 6.

Profil Tegangan Studi Kasus 1

\begin{tabular}{|c|c|c|c|c|c|}
\hline \multicolumn{6}{|c|}{ Case 1} \\
\hline $\begin{array}{l}\text { Wind } \\
\text { Power }\end{array}$ & $0 \mathrm{MW}$ & $\begin{array}{l}14.54 \\
\text { MW }\end{array}$ & $\begin{array}{l}55.79 \\
\text { MW }\end{array}$ & $\begin{array}{l}98.12 \\
\text { MW }\end{array}$ & $\begin{array}{l}113 \\
\text { MW }\end{array}$ \\
\hline Probability & $6.89 \%$ & $\begin{array}{c}20.44 \\
\%\end{array}$ & $\begin{array}{c}40.48 \\
\%\end{array}$ & $\begin{array}{c}19.92 \\
\%\end{array}$ & $\begin{array}{c}12.27 \\
\%\end{array}$ \\
\hline Bus & $\begin{array}{c}\text { Voltage } \\
(\mathrm{pu})\end{array}$ & $\begin{array}{c}\text { Voltage } \\
(\mathrm{pu})\end{array}$ & $\begin{array}{l}\text { Voltage } \\
\text { (pu) }\end{array}$ & $\begin{array}{c}\text { Voltage } \\
(\mathrm{pu})\end{array}$ & $\begin{array}{c}\text { Voltage } \\
(\mathrm{pu})\end{array}$ \\
\hline 1 & 1.060 & 1.060 & 1.060 & 1.060 & 1.060 \\
\hline 2 & 1.013 & 1.010 & 1.010 & 1.030 & 1.030 \\
\hline 3 & 1.009 & 1.004 & 1.001 & 1.008 & 1.008 \\
\hline 4 & 1.003 & 0.997 & 0.994 & 1.001 & 1.001 \\
\hline 5 & 1.010 & 1.010 & 1.010 & 1.010 & 1.010 \\
\hline 6 & 1.004 & 0.998 & 0.996 & 1.000 & 1.000 \\
\hline 7 & 0.999 & 0.995 & 0.994 & 0.996 & 0.996 \\
\hline 8 & 1.010 & 1.000 & 1.000 & 1.000 & 1.000 \\
\hline 9 & 1.036 & 1.033 & 1.031 & 1.034 & 1.034 \\
\hline 10 & 1.019 & 1.015 & 1.013 & 1.016 & 1.016 \\
\hline 11 & 1.082 & 1.082 & 1.082 & 1.082 & 1.082 \\
\hline 12 & 1.048 & 1.044 & 1.044 & 1.046 & 1.046 \\
\hline 13 & 1.071 & 1.071 & 1.071 & 1.071 & 1.071 \\
\hline 14 & 1.030 & 1.027 & 1.026 & 1.029 & 1.029 \\
\hline 15 & 1.023 & 1.020 & 1.019 & 1.021 & 1.021 \\
\hline 16 & 1.028 & 1.024 & 1.023 & 1.025 & 1.025 \\
\hline 17 & 1.016 & 1.013 & 1.011 & 1.013 & 1.014 \\
\hline 18 & 1.009 & 1.006 & 1.004 & 1.007 & 1.007 \\
\hline 19 & 1.004 & 1.000 & 0.999 & 1.001 & 1.002 \\
\hline 20 & 1.007 & 1.003 & 1.001 & 1.004 & 1.004 \\
\hline 21 & 1.006 & 1.002 & 1.000 & 1.003 & 1.003 \\
\hline 22 & 1.007 & 1.003 & 1.000 & 1.003 & 1.003 \\
\hline 23 & 1.007 & 1.003 & 1.002 & 1.005 & 1.005 \\
\hline 24 & 0.994 & 0.990 & 0.988 & 0.992 & 0.992 \\
\hline 25 & 0.996 & 0.990 & 0.990 & 0.993 & 0.993 \\
\hline 26 & 0.978 & 0.972 & 0.971 & 0.975 & 0.975 \\
\hline 27 & 1.006 & 1.000 & 0.999 & 1.003 & 1.003 \\
\hline 28 & 1.001 & 0.994 & 0.992 & 0.996 & 0.996 \\
\hline 29 & 0.986 & 0.979 & 0.979 & 0.982 & 0.983 \\
\hline 30 & 0.974 & 0.968 & 0.967 & 0.971 & 0.971 \\
\hline $\begin{array}{l}\text { Operation } \\
\text { cost }(\$ / h)\end{array}$ & 9532.5 & 9386.8 & 9005.6 & 8776.9 & 8750.4 \\
\hline $\begin{array}{l}\text { Deviasi } \\
\text { tegangan }\end{array}$ & 2.3996 & 2.3295 & 2.3109 & 2.4087 & 2.4082 \\
\hline $\begin{array}{c}\text { Perkiraan } \\
\text { biaya } \\
\text { operasi }\end{array}$ & & & $9042.95 \$ / \mathrm{h}$ & & \\
\hline
\end{tabular}

energi pada kondisi terburuk, yaitu dengan asumsi daya keluaran pembangkit tenaga angin bernilai nol. Telah diperoleh alokasi sistem penyimpan energi terbaik, yaitu bus 4, 17, 28 dan 29 dengan kapasitas sistem penyimpan energi pada masing masing bus sebesar 1.5, 1.5, 14 dan 11.5 MW. Kemudian sistem dioperasikan pada 5 skenario berbeda. Dan hasilnya dapat dilihat pada tabel 7. Jika dibandingkan dengan hasil studi kasus 1, biaya operasi sistem berkurang secara signifikan. Deviasi tegangan yang diperoleh juga terlihat lebih baik dibandingkan hasil dari studi kasus 1.

(3) Studi Kasus 3

Pada studi kasus ketiga, digunakan metode HMOPSO untuk menentukan alokasi sistem penyimpan energi pada sistem yang mempertimbangkan distribusi tenaga angin. Dalam metode HMOPSO, setiap load bus akan diinisialisasikan sistem penyimpanan energi dengan kapasitas acak, kemudian kapasitas sistem penyimpan energi pada setiap bus akan diperbarui terus menerus, sampai diperoleh alokasi terbaik. Jika terdapat kapasitas sistem penyimpan energi yang bernilai nol pada suatu bus, maka hal tersebut menandakan bahwa pada bus
Tabel 7.

Profil Tegangan Studi Kasus 2

\begin{tabular}{|c|c|c|c|c|c|}
\hline \multicolumn{6}{|c|}{ Case 2} \\
\hline Wind & \multirow{2}{*}{$0 \mathrm{MW}$} & 14.54 & 55.79 & 98.12 & 113 \\
\hline Power & & MW & MW & MW & MW \\
\hline \multirow{2}{*}{ Probability } & \multirow{2}{*}{$6.89 \%$} & 20.44 & 40.48 & 19.92 & 12.27 \\
\hline & & $\%$ & $\%$ & $\%$ & $\%$ \\
\hline Bus & $\begin{array}{l}\text { Voltage } \\
\text { (pu) }\end{array}$ & $\begin{array}{l}\text { Voltage } \\
\text { (pu) }\end{array}$ & $\begin{array}{l}\text { Voltage } \\
\text { (pu) }\end{array}$ & $\begin{array}{l}\text { Voltage } \\
\text { (pu) }\end{array}$ & $\begin{array}{c}\text { Voltage } \\
\text { (pu) }\end{array}$ \\
\hline 1 & 1.060 & 1.060 & 1.060 & 1.060 & 1.060 \\
\hline 2 & 1.013 & 1.010 & 1.010 & 1.030 & 1.030 \\
\hline 3 & 1.010 & 1.004 & 1.004 & 1.011 & 1.011 \\
\hline 4 & 1.003 & 0.998 & 0.997 & 1.004 & 1.004 \\
\hline 5 & 1.010 & 1.010 & 1.010 & 1.010 & 1.010 \\
\hline 6 & 1.006 & 0.999 & 0.998 & 1.002 & 1.002 \\
\hline 7 & 1.000 & 0.995 & 0.995 & 0.998 & 0.998 \\
\hline 8 & 1.010 & 1.000 & 1.000 & 1.000 & 1.000 \\
\hline 9 & 1.037 & 1.033 & 1.033 & 1.035 & 1.035 \\
\hline 10 & 1.020 & 1.015 & 1.014 & 1.017 & 1.017 \\
\hline 11 & 1.082 & 1.082 & 1.082 & 1.082 & 1.082 \\
\hline 12 & 1.047 & 1.045 & 1.045 & 1.047 & 1.047 \\
\hline 13 & 1.071 & 1.071 & 1.071 & 1.071 & 1.071 \\
\hline 14 & 1.030 & 1.027 & 1.027 & 1.030 & 1.030 \\
\hline 15 & 1.024 & 1.020 & 1.020 & 1.023 & 1.023 \\
\hline 16 & 1.028 & 1.025 & 1.024 & 1.027 & 1.027 \\
\hline 17 & 1.017 & 1.013 & 1.012 & 1.015 & 1.015 \\
\hline 18 & 1.010 & 1.006 & 1.006 & 1.008 & 1.008 \\
\hline 19 & 1.005 & 1.001 & 1.000 & 1.003 & 1.003 \\
\hline 20 & 1.008 & 1.003 & 1.003 & 1.006 & 1.006 \\
\hline 21 & 1.007 & 1.002 & 1.002 & 1.005 & 1.005 \\
\hline 22 & 1.008 & 1.003 & 1.002 & 1.005 & 1.005 \\
\hline 23 & 1.009 & 1.005 & 1.005 & 1.007 & 1.007 \\
\hline 24 & 0.998 & 0.993 & 0.992 & 0.995 & 0.995 \\
\hline 25 & 1.004 & 0.999 & 0.999 & 1.002 & 1.002 \\
\hline 26 & 0.986 & 0.981 & 0.981 & 0.984 & 0.984 \\
\hline 27 & 1.017 & 1.011 & 1.011 & 1.014 & 1.014 \\
\hline 28 & 1.006 & 0.998 & 0.998 & 1.001 & 1.001 \\
\hline 29 & 1.015 & 1.009 & 1.009 & 1.012 & 1.013 \\
\hline 30 & 0.996 & 0.990 & 0.990 & 0.993 & 0.993 \\
\hline $\begin{array}{l}\text { Operation } \\
\text { cost }(\$ / \mathrm{h})\end{array}$ & 9479.1 & 9315.5 & 8942.5 & 8781.0 & 8774.4 \\
\hline $\begin{array}{l}\text { Deviasi } \\
\text { tegangan }\end{array}$ & 2.3571 & 2.1674 & 2.1588 & 2.3499 & 2.3524 \\
\hline $\begin{array}{l}\text { Alokasi } \\
\text { penyimpan } \\
\text { energi }\end{array}$ & \multirow{2}{*}{\multicolumn{5}{|c|}{$\begin{array}{l}\text { Bus 4/1.5 MW, Bus 17/1.5, Bus 28/14 MW dan Bus } \\
\text { 29/11.5 MW }\end{array}$}} \\
\hline Total & & & & & \\
\hline $\begin{array}{l}\text { kapasitas } \\
\text { penyimpan } \\
\text { energi }\end{array}$ & \multicolumn{5}{|c|}{$28.5 \mathrm{MW}$} \\
\hline Perkiraan & \multirow{2}{*}{\multicolumn{5}{|c|}{$9002.92 \$ / \mathrm{h}$}} \\
\hline $\begin{array}{l}\text { biaya } \\
\text { operasi }\end{array}$ & & & & & \\
\hline
\end{tabular}

tersebut tidak diperlukan instalasi sistem penyimpan energi. Dapat dilihat dari hasil studi kasus 3 pada tabel 8, bahwa biaya operasi sistem jauh lebih murah dibandingkan biaya operasi sistem pada studi kasus 2. Deviasi tegangan yang diperoleh juga lebih baik dibandingkan hasil studi kasus 2. Dengan hasil yang diperoleh jika sistem dioperasikan selama satu tahun, maka biaya operasi akan lebih hemat sebesar 496800 \$ttahun.

(4) Perbandingan hasil

Perbandingan biaya operasi sistem dari ketiga studi kasus tersebut dapat dilihat pada gambar 5. Sedangkan perbandingan deviasi tegangan sistem dari ketiga studi kasus tersebut dapat dilihat pada gambar 6. Diantara studi kasus 1, studi kasus 2 dan studi kasus 3, hasil yang diperoleh dari studi kasus 3 adalah yang terbaik. Dengan biaya operasis sistem yang paling murah. Dan deviasi tegangan yang paling rendah. 
Tabel 8.

Profil Tegangan Studi Kasus 3

\begin{tabular}{|c|c|c|c|c|c|}
\hline \multicolumn{6}{|c|}{ Case 3} \\
\hline Wind & $0 \mathrm{MW}$ & 14.54 & 55.79 & 98.12 & 113 \\
\hline Power & $0 \mathrm{MW}$ & MW & MW & MW & MW \\
\hline \multirow{2}{*}{ Probability } & \multirow{2}{*}{$6.89 \%$} & 20.44 & 40.48 & 19.92 & 12.27 \\
\hline & & $\%$ & $\%$ & $\%$ & $\%$ \\
\hline Bus & $\begin{array}{l}\text { Voltage } \\
\text { (pu) }\end{array}$ & $\begin{array}{l}\text { Voltage } \\
(\mathrm{pu})\end{array}$ & $\begin{array}{l}\text { Voltage } \\
\text { (pu) }\end{array}$ & $\begin{array}{c}\text { Voltage } \\
(\mathrm{pu})\end{array}$ & $\begin{array}{l}\text { Voltage } \\
(\mathrm{pu})\end{array}$ \\
\hline 1 & 1.060 & 1.060 & 1.060 & 1.060 & 1.060 \\
\hline 2 & 1.013 & 1.010 & 1.010 & 1.030 & 1.030 \\
\hline 3 & 1.009 & 1.004 & 1.003 & 1.009 & 1.009 \\
\hline 4 & 1.003 & 0.997 & 0.996 & 1.003 & 1.003 \\
\hline 5 & 1.010 & 1.010 & 1.010 & 1.010 & 1.010 \\
\hline 6 & 1.005 & 0.998 & 0.997 & 1.001 & 1.001 \\
\hline 7 & 0.999 & 0.995 & 0.994 & 0.997 & 0.997 \\
\hline 8 & 1.010 & 1.000 & 1.000 & 1.000 & 1.000 \\
\hline 9 & 1.037 & 1.033 & 1.032 & 1.035 & 1.035 \\
\hline 10 & 1.019 & 1.015 & 1.013 & 1.016 & 1.016 \\
\hline 11 & 1.082 & 1.082 & 1.082 & 1.082 & 1.082 \\
\hline 12 & 1.047 & 1.044 & 1.044 & 1.047 & 1.047 \\
\hline 13 & 1.071 & 1.071 & 1.071 & 1.071 & 1.071 \\
\hline 14 & 1.030 & 1.027 & 1.026 & 1.029 & 1.029 \\
\hline 15 & 1.024 & 1.020 & 1.020 & 1.022 & 1.022 \\
\hline 16 & 1.028 & 1.025 & 1.023 & 1.026 & 1.026 \\
\hline 17 & 1.017 & 1.013 & 1.011 & 1.014 & 1.014 \\
\hline 18 & 1.010 & 1.006 & 1.005 & 1.008 & 1.008 \\
\hline 19 & 1.005 & 1.001 & 0.999 & 1.002 & 1.002 \\
\hline 20 & 1.008 & 1.004 & 1.002 & 1.005 & 1.005 \\
\hline 21 & 1.007 & 1.003 & 1.001 & 1.004 & 1.004 \\
\hline 22 & 1.008 & 1.003 & 1.002 & 1.005 & 1.005 \\
\hline 23 & 1.009 & 1.005 & 1.004 & 1.007 & 1.007 \\
\hline 24 & 0.998 & 0.993 & 0.992 & 0.995 & 0.995 \\
\hline 25 & 1.005 & 1.000 & 0.999 & 1.003 & 1.003 \\
\hline 26 & 0.997 & 0.991 & 0.991 & 0.994 & 0.994 \\
\hline 27 & 1.015 & 1.009 & 1.008 & 1.012 & 1.012 \\
\hline 28 & 1.004 & 0.996 & 0.995 & 0.998 & 0.998 \\
\hline 29 & 1.002 & 0.996 & 0.996 & 0.999 & 0.999 \\
\hline 30 & 0.998 & 0.992 & 0.992 & 0.995 & 0.995 \\
\hline $\begin{array}{l}\text { Operation } \\
\text { cost }(\$ / h)\end{array}$ & 9509.3 & 9338.3 & 8899.9 & 8646.5 & 8609.8 \\
\hline $\begin{array}{c}\text { Deviasi } \\
\text { tegangan }\end{array}$ & 2.3008 & 2.1195 & 2.0856 & 2.2779 & 2.2779 \\
\hline $\begin{array}{l}\text { Alokasi } \\
\text { penyimpan } \\
\text { energi }\end{array}$ & \multicolumn{5}{|c|}{ Bus 26/3.5 MW dan Bus 30/7.5 MW } \\
\hline Total & \multirow{2}{*}{\multicolumn{5}{|c|}{$11 \mathrm{MW}$}} \\
\hline $\begin{array}{l}\text { kapasitas } \\
\text { penyimpan } \\
\text { energi }\end{array}$ & & & & & \\
\hline Perkiraan & \multirow{2}{*}{\multicolumn{5}{|c|}{$8945.42 \$ / \mathrm{h}$}} \\
\hline $\begin{array}{l}\text { biaya } \\
\text { operasi }\end{array}$ & & & & & \\
\hline
\end{tabular}

\section{KESIMPULAN}

Dengan meningkatnya penggunaan pembangkit listrik tenaga angin, maka dalam menentukan lokasi dan ukuran sistem penyimpan energi sangat penting untuk mempertimbangkan ketidak-pastian tenaga angin. Metode 5PEM digunakan untuk mendiskritisasi distribusi tenaga angin yang kontinyu menjadi 5 poin diskrit distribusi tenaga angin yang kemudian dijadikan 5 skenario untuk diperhitungkan dalam alokasi sistem penyimpan energi. Dengan mempertimbangkan distribusi tenaga angin, metode HMOPSO dapat menentukan lokasi dan ukuran sistem penyimpan energi dengan hasil biaya operasi sistem yang lebih murah dan deviasi tegangan sistem yang lebih baik.

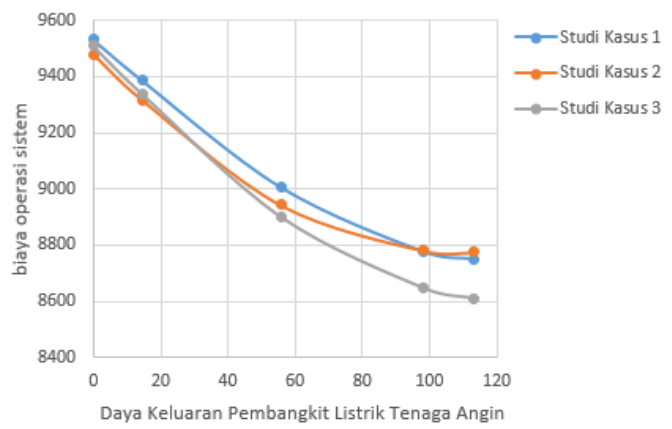

Gambar 5. Perbandingan biaya operasi sistem dari ketiga studi kasus.

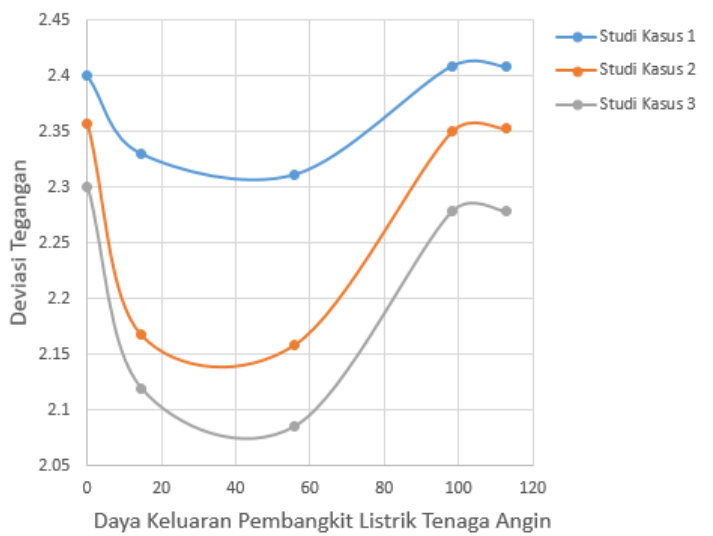

Gambar 6. perbandingan deviasi tegangan sistem dari ketiga studi kasus

\section{DAFTAR PUSTAKA}

[1] F. Blaabjerg, Z. Chen, and S. B. Kjaer, "Power electronics as efficient interface in dispersed power generation systems," IEEE Trans. Power Electron., vol. 19, no. 5, pp. 1184-1194, 2004.

[2] S. Sims, "AWEA U . S . Wind Industry Annual Market Report Andy Swapp," 2010.

[3] T. H. Yeh and L. Wang, "A study on generator capacity for wind turbines under various tower heights and rated wind speeds using Weibull distribution," IEEE Trans. Energy Convers., vol. 23, no. 2, pp. 592-602, 2008.

[4] Q. Fu et al., "Microgrid generation capacity design with renewables and energy storage addressing power quality and surety," IEEE Trans. Smart Grid, vol. 3, no. 4, pp. 2019-2027, 2012.

[5] S. Wen, H. Lan, Q. Fu, C. Y. David, and L. Zhang, "Economic allocation for energy storage system considering wind power distribution," IEEE Trans. Power Syst., vol. 30, no. 2, pp. 644-652, 2015.

[6] C. Su, "Probabilistic Load-Flow Computation," vol. 20, no. 4, pp. 1843-1851, 2005.

[7] K. Mahesh, P. Nallagownden, and I. Elamvazuthi, "Advanced Pareto front non-dominated sorting multi-objective particle swarm optimization for optimal placement and sizing of distributed generation," Energies, vol. 9, no. 12, p. 982, 2016.

[8] M. B. Ã and R. Wiser, "Wind power price trends in the United States : Struggling to remain competitive in the face of strong growth $\$$," vol. 37, pp. 1061-1071, 2009.

[9] R. Wiser and M. Bolinger, "Annual Report on U . S . Wind Power Installation, Cost , and Performance Trends : 2007 Contents."

[10] J. Eyer, "Energy Storage for the Electricity Grid: Benefits and Market Potential Assessment Guide A Study for the DOE Energy Storage Systems Program," no. February, 2010. 